\title{
Felnőttkori atopiás dermatitis hipnoterápiás kezelése
}

\author{
Perczel Kristóf dr.* - Gál János dr.
}

Semmelweis Egyetem, Általános Orvostudományi Kar, Aneszteziológiai és Intenzív Terápiás Klinika, Budapest

\begin{abstract}
A hipnózis moduláló hatása immun- és gyulladásos folyamatokban már számos kutatással alátámasztott. Ismert, hogy terápiás lehetőséget nyújthat számos inflammatorikus patogenezisű kórképben. Esettanulmányukban a szerzők beszámolnak egy gyógyszeres terápiára csupán minimálisan reagáló, felnőttkori, kiterjedt atopiás dermatitises férfi hipnoterápiás kezeléséről. Tizenöt üléses hipnoterápia során párhuzamosan használtak direkt tünetorientált szuggesztív technikákat, valamint a komorbid pszichés múködéseket feltáró és módosító hipnoterápiás elemeket. A kezelés hatásának követésére páciensnaplókat (alvás és fájdalom), valamint ismételten felvett pszichometrikus teszteket alkalmaztak. A terápiás munka végére mind klinikailag, mind a mérhető mutatók alapján nagyfokú javulást értek el az összes vizsgált dimenzióban (viszketés, fájdalom, alvászavar, aktivitás, szorongás és hangulati állapot). A szerzők következtetése szerint a hipnoterápia hatékony kiegészítője lehet atopiás dermatitises páciensek farmakoterápiájának, valamint mentő terápiát jelenthet egyes, terápiás kudarcnak tünő esetekben. Orv. Hetil., 2016, 157(3), 111-115.
\end{abstract}

Kulcsszavak: hipnózis, atopiás dermatitis, pszichoszomatikus orvoslás, gyulladás

\section{Hypnotherapy of atopic dermatitis in an adult}

\section{Case report}

Hypnosis is well known for its modulatory effects on immune and inflammatory processes, and it is a therapeutic option for certain diseases of such pathogenesis. The authors report treatment of an adult patient with extensive atopic dermatitis, who was only minimally responsive to conservative treatment. In a 15 session hypnotherapy the authors combined the use of direct, symptom-oriented suggestive techniques with hypnotic procedures to identify and modify comorbid psychological issues. To monitor the effect of the treatment, patient diaries (quality and quantity of sleep, intensity of pain and itch) and repeated psychometric tests were used. At the end of treatment there were improvements in all measured dimensions (itch, pain, insomnia, activity, anxiety and emotional state) both clinically and psychometrically. The authors conclude, that hypnosis can be an effective adjunctive therapy in atopic dermatitis, and in certain severe cases may constitute a salvage therapy.

Keywords: hypnosis, atopic dermatitis, psychosomatic medicine, inflammation

Perczel, K., Gál, J. [Hypnotherapy of atopic dermatitis in an adult]. Orv. Hetil., 2016, 157(3), 111-115.

(Beérkezett: 2015. szeptember 29.; elfogadva: 2015. december 3.)

\author{
Rövidítések \\ BDI $=($ Beck Depression Inventory $)$ Beck Depresszió Kérdőív; \\ DAS $=($ Dysfunctional Attitude Scale $)$ Diszfunkcionális Attitüd \\ Skála; PLEQ-R = Paykel-féle Életesemény Kérdőív (rövidített); \\ SCORAD $=($ Scoring Atopic Dermatitis $)$ Atopiás Dermatitis
}

Pontszám; SHAI = (Health Anxiety Inventory - short version $)$ Egészség-szorongás Kérdő́iv; STAI-T, STAI-S = (State-Trait Anxiety Inventory) Vonás és Állapot Szorongás Kérdőív; WHYMPI = (The West Haven-Yale Multidimensional Pain Inventory) Többdimenziós Fájdalom Kérdőív 
Az atopiás dermatitis (vagy ekcéma) egy gyakori, gyulladásos bőrbetegség, amelynek diagnózisa a viszketés, a jellegzetes morfológia (lichenificatio) és a krónikus, recidiváló kórlefolyás hármasán nyugszik. Kezdete jellemzően az első életévekre esik: fejlett országokban prevalenciajja gyermekkorban 15-30\% közé tehető, amely az életkorral csökken, s felnőttkorban már csupán 1\% körüli [1]. Azoknál a betegeknél, akiknél nem alakul ki spontán remisszió a kamaszkorban, jellemzően elhúzódó, időszakos fellángolásokkal leírható krónikus folyamat figyelhető meg. A betegség terhe óriási: a folyamatos, kínzó viszketés nappal a szociális és szakmai múködést ássa alá (amelyet az esztétikai problémák is kikezdenek), éjjel pedig gyakran súlyos alvászavart okoz. A betegség anyagi terhe összemérhető a diabetes mellituséval [1] a kezelési költségek s a munkából való kimaradás okán. A bőrgyógyászati kezelés gerincét a topikus (súlyos esetben szisztémás) antiinflammatorikus terápia képezi (kortikoszteroidok vagy kalcineuringátlók formájában), amely az insomnia kezelése céljából szedatív hatású antihisztaminokkal egészíthető ki [2]. Sajnos, az említett gyógyszercsoportok mellékhatásai igen súlyosak lehetnek, ugyanakkor gyakran csupán átmeneti tüneti enyhüléshez vezetnek: jól dokumentált az atopiás dermatitises betegek csökkent életminősége [3].

Holisztikusabb perspektívából tekintve az atopiás betegségekre, jól felismerhető a szorongás, a megterhelő élethelyzetek szerepe a betegség lefolyásában. Bár az öszszefüggés létét a páciensek és klinikusok közül is talán kevesen vonnák kétségbe, mégis tudományos megragadhatóságának nehézségei miatt az orvostársadalom gyakran óvakodik attól, hogy a pszichés tényezőket releváns terápiás célpontnak tekintse. Ugyanakkor a pszichoneuroimmunológiai kutatások gyarapodó eredményei újabb és újabb kapcsolatokat tárnak fel az immun- és hormonrendszer, valamint a pszichés múködések között [4]. Ezen ismeretek fényében egyre inkább molekulárisan is megalapozottnak tekinthető a hagyományos kezelések kiegészítése olyan elemekkel, amelyek a pszichés múködések módosítása révén alakítják a kórkép alapját képező krónikus gyulladásos folyamatot.

Az ismert pszichoterápiás kezelések közül a hipnózis neuromodulatív hatása mind idegélettani, mind klinikai szempontból bizonyítottnak tekinthető [5]. Jelen esetismertetésünkben a hipnózis rövid bemutatását követően a farmakoterápiára csupán minimálisan reagáló, kiterjedt atopiás dermatitises fiatalember hipnoterápiájáról számolunk be.

\section{Hipnózis}

Hipnózisszerû, vagyis szuggesztív technikákon alapuló kezeléseket nagyszámban találunk a gyógyítás történetében, ugyanakkor a ma orvosi hipnózisnak nevezett eljárás alapjait Európában Franz Anton Mesmer fektette le a XVIII. században. Az akkor még tudományosan igencsak megfoghatatlan tevékenység megértése az elmúlt
230 évben rengeteget fejlődött. Objektív vizsgálata először a kísérleti pszichológia számára vált elérhetővé (az 1950-es években), majd napjainkban a neurofiziológiai kutatások számára is. Ez az izgalmas történet, valamint mai tudásunk áttekinthető a közelmúlt magyar öszszefoglalóiban $[6,7]$.

De miról is beszélünk, amikor a hipnózis kifejezést használjuk? Sokak szeme előtt bizonyára egy lengedező zsebóra jelenik meg, amely az említett franciaországi kezdetekhez köthető kép. A ma elfogadott definíció szerint egy „... olyan folyamat, amelyben az egyik személy (a hipnotizôr) egy másik személynek (a hipnotizáltnak) elképzelt élményekre vonatkozó szuggesztiókat ad, amelyek megváltozott érzékeléssel, emlékezettel és akarati cselekvéssel járnak. Klasszikus esetben ez az élmény és a vele társuló viselkedés érzékcsalódással határos szubjektiv meggyöződéssel és kényszerrel határos akaratvesztéssel társul. Így a hipnózis jelenségei a tudat társas interakció kontextusában létrejövő módosulásait tükrözik” [8].

Az egyén szubjektív élményvilága tehát gyökeresen átformálható hipnózisban: klasszikus hipnotikus jelenségek az önkéntelenség élményét nyújtó motoros (például karlevitatio, végtagcatalepsia) és szenzoros (analgesia, pozitív és negatív hallucináció) próbák. A megélt szubjektív változások testiekkel járnak együtt, és így akaratlagosan nem befolyásolható folyamatok válnak módosíthatóvá. Gondolhatunk itt a hétköznapi tapasztalatra, ahogyan minden akaraterőnk kevés arcunk vérátáramlásának csökkentéséhez, ugyanakkor a megfelelő személy egyetlen szava is elég lehet ahhoz, hogy elsápadjunk. Ennek az egyszerü megfigyelésnek a klinikai jelentősége óriási lehet olyan kórállapotokban, ahol a keringés módosításával gyulladásos folyamatok válnak befolyásolhatóvá: Ewin sürgősségi osztályon hipnózissal sikeresen gátolta súlyos égési sérültek bőrelváltozásainak progreszszióját [9]. Hasonló módon (a szubjektív élményvilág és a társuló mikrocirkulációs, inflammatorikus és immunfunkciók módosításával) olyan klinikai problémák javulásáról állnak rendelkezésre tanulmányok (a teljesség igénye nélkül), mint az akut és krónikus fájdalom, a perioperatív vérvesztés, a kemoterápia asszociálta hányás és hányinger vagy az irritábilis bél szindróma [5, 10-13]. Mindezek ismeretében talán kevéssé meglepő, hogy egy olyan betegségben, mint az atopiás dermatitis, ahol a gyulladás szintén kulcsszerepet játszik a patogenezisben, hatékony terápiás eszköz lehet a hipnoterápia $[14,15]$.

\section{Esetismertetés}

A 32 éves férfi anamnéziséből csecsemőkora óta fennálló atopiás dermatitisén kívül csupán inhalatív, valamint epicutan allergénekre adott fokozott reakció emelhető ki. Állapota kamaszkorát követően jelentősen javult, húszés huszonhat éves kora között szinte tünetmentes volt.

Szerológiailag igazolt Lyme-kór miatt 26 éves korában 12 hetes doxycyclin- és tinidazolkúrában részesült, amelyet követően bőrtünetei rapid progressziót mutat- 
tak, végül impetiginisatio és súlyosan elesett állapot miatt kórházi felvétele is szükségessé vált. Fekvőbeteg-ellátása során szisztémás antibiotikus és lokális antiszeptikus kezelés mellett gyulladásos eltérései regressziót mutattak, általános állapota jelentősen javult. Távozását követően azonban intenzív topikus (mometason [ung. Elocom] $0,1 \%$, pimecrolimus [ung. Protopic] $0,1 \%$ és nem szedatív antihisztamin (fexofenadin [tabletta Altiva] E: 180 mg) kezelés mellett állapota folyamatos romlást mutatott. Insomniájának kezelése céljából átmenetileg neuroleptikus kezelésben részesült (hydroxyzin [tabletta Atarax] E: $25 \mathrm{mg}$ ), amely problémáján érdemben javítani nem tudott. Ambulanter módon 10 alkalmas UV-B fototerápia is történt valódi siker nélkül. Az első kórházi felvételét követő másfél évben négy alkalommal állt kezelés alatt ekzema herpeticum miatt; egy alkalommal parenteralis antivirális kezelés is szükségessé vált.

Jelentkezése idején bőrgyógyászati vizsgálat betegségét kiterjedtnek minősítette (SCORAD-pontérték 3560 között) a naponta többszöri emolliens kezelés és topikus kortikoszteroid mellett. Szubjektív problémahierarchiájának csúcsára alvászavarát helyezte: havonta átlagosan egy éjszakát tudott végigaludni, a többi éjszakát sokórányi álmatlan forgolódással és vakaródzással jellemezte. Emellett igen nagyfokú fájdalomról számolt be az érintett területeken, amely jelentős mértékben korlátozta szociális tevékenységében.

Páciensünkkel 15 üléses hipnoterápiás kezelést végeztünk, amelynek eredményeit többszöri pszichometriai vizsgálattal, valamint a páciens által vezetett viszketés- és alvásnapló segítségével követtük. A heti egyszeri ülések között otthoni gyakorlásában hangfelvételek készítésével segítettük. Ismételten felvettük a következő önkitöltős kérdőíveket: Beck Depresszió Kérdőív (BDI) [16], Spielberger-féle Vonás és Állapot Szorongás Kérdőív (STAI-T, STAI-S) [17], Egészség-szorongás Kérdőív (SHAI) [18], Többdimenziós Fájdalom Kérdőív (WHYMPI) [19], Paykel-féle Életesemény Kérdőív (PLEQ-R) [20], Diszfunkcionális Attitűd Skála (DAS) [21]. A kezelés megkezdését megelőzően a hipnózisról páciensünket részletesen felvilágosítottuk, majd írásbeli beleegyezését kértük.

A közös pszichoterápiás munka során párhuzamosan törekedtünk a háttérben húzódó intrapszichés és szociális mechanizmusok megértésére és alakítására, a megterhelő életesemények és stresszorok feltárására, illetve átkeretezésére, valamint a tünetek célzott szuggesztiókkal való enyhítésére. Ez utóbbi célt megvalósító hipnózisülésekről hangfelvétel készült a páciens otthoni gyakorlását elősegítendő, amely eljárás hatékonyságot növelő hatása jól dokumentált a krónikus fájdalomszindrómával kezelt betegeknél [22].

Első terápiás célunk a súlyos insomnia enyhítése volt, amelynek hátterében az éjszakai viszketés, valamint a kialvatlanságtól való félelem okozta egyre fokozódó feszültség volt feltárható. Eszközként hangfelvételt készítettünk olyan hipnózisülésünkről, amelynek során ellazulást elősegítő és direkt tünetcsökkentő szuggesztiókat alkalmaztunk. Aspecifikus hatótényezóként meg kell említenünk a hipnotikus állapot azon jellemzőjét, hogy megfelelő körülmények között könnyen alakul át természetes alvássá (amely jelenség hátterében többek között a hipnózisindukciók EEG-vel mérhető alfa-aktivitást növelő hatása áll) [23].

Az alvászavar kezelésével párhuzamosan törekedtünk a felnőttkori állapotromlással egybeeső megterhelő életesemények feltárására, átkeretezésére és ezáltal ezek érzelmi intenzitásának csökkentésére. Ennek során a fokozott viszketést kiváltó helyzetek számos jellemzőjét sikerült azonosítani, amely tudás birtokában már lehetségessé vált a fenyegető szituációk (stresszorok) korai felismerése és ezáltal adaptívabb válaszok kidolgozása. Páciensünk megfogalmazása szerint kulcsfontosságú volt annak megértése, „miként tudja feszültségét nem a tíz körmével a bőrén levezetni”.

A fájdalom és a viszketés kellemetlen szenzoros élményének enyhítésére a hipnózis eszköztárának talán legismertebb elemét, a hipnotikus anesztéziát alkalmaztuk. Ennek köszönhetően páciensünk egyre nagyobb kontrollra tett szert panaszai felett, amellyel párhuzamosan lehetségessé vált fókuszának áthelyezése a tünetekről (azok meglétéról, illetve hiányáról) a számára fontos életfeladatokra és tevékenységekre.

Páciensünk szubjektív beszámolói mellett standard pszichometrikus eszközöket, valamint alvás- és viszketésnaplót használtunk kezelésünk hatásának követésére. A használt skálákkal kimutatható volt a javulás a hangulati állapotban, a megélt szorongás fokában, a panaszok intenzitásában, az azok felett érzett kontrollban, valamint azok mindennapokra gyakorolt hatásában (1. táblázat).

1. táblázat |A felvett pszichometriai tesztek releváns eredményei

\begin{tabular}{llll}
\hline & Kezelés előtt & 12. ülés idején & $\begin{array}{l}\text { Kezelés után } \\
(15 . \text { ülés idején })\end{array}$ \\
\hline VF-intenzitás & $3,7 / 6$ & & $2 / 6$ \\
VF-kontroll & $2 / 6$ & & $3 / 6$ \\
VF-zavar & $4 / 6$ & & $0,9 / 6$ \\
VF-aktivitás & $2,75 / 6$ & & $2,6 / 6$ \\
BDI & 15 & 3 & 6 \\
STAI-T & 42 & 36 & 33 \\
STAI-S & 50 & 40 & 38 \\
SHAI & 20 & & 6 \\
\hline
\end{tabular}

VF-intenzitás = Többdimenziós Fájdalom Kérdőív, intenzitás alskála; VF-kontroll = Többdimenziós Fájdalom Kérdőív, kontroll alskála; VF-zavar = Többdimenziós Fájdalom Kérdőív, „életminőségre gyakorolt hatás" alskála; VF-aktivitás = Többdimenziós Fájdalom Kérdőív, aktivitás alskála [19]; BDI = Beck Depresszió Kérdőív [16]; STAI-T = Vonás Szorongás Kérdőív; STAI-S = Állapot Szorongás Kérdőív [17]; SHAI = Egészség-szorongás Kérdő́ív [18]. 
Az alvás mennyisége és minősége 10 ülés során óriási javulást mutatott: a tízfokú skálán osztályozott alvásminőség (ahol „0" az egyáltalán nem kielégítő és „10” a teljes mértékben kielégítő alvásminőség) 3-ról 8-ra emelkedett; a többórányi kimerítő forgolódás helyét átvették a gyors és feszültségmentes visszaalvások az esetleges megébredések esetén. A havonta átaludt éjszakák száma 1-2-ről 23-25-re nőtt az alvásnapló adatai alapján.

A viszketés intenzitása a tízfokú skálán 7-ről 4-re csökkent, s megszünt fájdalmas jellege. A szenzoros élmény csökkenésénél azonban jóval nagyobb mértékű változás következett be a napi tevékenységekre gyakorolt hatásában: a viszketés rendkívül kellemetlen zavaró jellegének intenzitása 8 pontról (nagymértékben zavaró) 2 pontra (alig zavaró) csökkent. Az első találkozásunkkor betegsége tünetei és kezelése által teljesen lekötött, az alváshiánytól és a viszketéstől kimerült, minimális fizikai aktivitásra képes depressziós hangulatú $(\mathrm{BDI}=15)$ személy helyén az utolsó ülésen egy olyan férfi ült, akinek alvászavara rendeződött, kellemetlen bőrtünetei, ekcémája nagymértékben csökkentek, depresszív hangulata oldódott $(\mathrm{BDI}=3)$. Elmondása alapján már volt kedve és motivációja mindennapi tevékenységei elvégzéséhez, sietett haza gyerekeihez, valamint kerti asztalosmunkáihoz.

A terápiás munka lezárása után 3 hónappal kapott viszszajelzés alapján az elért változások nem csupán tartósnak bizonyultak, hanem a megindult pozitív változások tovább folytatódtak. Ugyan pszichometriai mérésre ez alkalommal nem került sor, de a páciens beszámolója alapján a topikus kortikoszteroid használata sokat csökkent (a terápia előtti heti 2-3-szori használat helyett jelenleg hetente 1-szer), alvásminősége kiváló és fizikai aktivitása nagy.

\section{Megbeszélés}

A fenti esetismertetés, véleményünk szerint, jól illusztrálja a hipnoterápia hatékonyságát bizonyos típusú gyulladásos kórképekben: egyszerre nyújt lehetőséget az inflammatorikus folyamat kontrolljára, a szenzoros élmények átalakítására, valamint a komorbid pszichés problémák, múködések feltárására és módosítására. Esetismertetésünk alapján szeretnénk továbbá hangsúlyozni az elért javulás tartósságát is, valamint a tényt, hogy a terápia során elsajátított készségekkel a páciens gyógyulása a közös munka lezárását követően tovább folytatódhat.

Az alkalmazott szuggesztiók célzott hatását mutatja az, hogy az első terápiás szakaszban (amely az alvászavar csökkentésére irányult) a nappali viszketés és fájdalom erőssége érdemi változást nem mutatott; javulása csupán a kezelés második szakaszában indult meg, amikor ezek a tünetek kerültek a hipnoterápia fókuszába. Ez azt is jelenti, hogy a hipnoterápia hatótényezői nem merülnek ki a szorongásoldás, relaxáció aspecifikus közérzetjavító és immunmoduláló hatásában, hanem egészen konkrét, szuggesztiófüggő múködésváltozásokhoz is vezetnek.
Érdekes kiemelni, hogy noha a korszerü pszichoterápiás munka nem nélkülözheti a számszerúsítés lehetőségét megteremtő pszichometriai eszközöket, mégis azoknak lehetnek korlátai is: esetünkben az aktivitás-alskálán (VF aktivitás alskála, 1. táblázat) nem volt kimutatható érdemi különbség a terápia előtti és utáni állapot között, míg klinikailag (valamint a páciens beszámolója alapján) egyértelmú volt, hogy éppen ebben a dimenzióban volt az egyik legnagyobb az állapotjavulás.

Összefoglalva úgy gondoljuk, hogy számos kórképcsoportnál fontos a felmerülő pszichés tényezőket terápiás célpontnak tekinteni, amennyiben a szomatikus kezelés nem hozza meg a várt javulást. Pácienseinket korszerü pszichoterápiás ellátáshoz segítve az meghozhatja az érdemi változást, mint ahogyan az ennél az ekcémás férfinál is történt [24].

Anyagi támogatás: A közlemény megírása anyagi támogatásban nem részesült.

Szerzői munkamegosztás: P. K.: Hipnoterápiás munka, a cikk megírása. G. J.: A közlemény kritikai átdolgozása. A cikk végleges változatát mindkét szerző elolvasta és jóváhagyta.

Érdekeltségek: A szerzőknek nincsenek érdekeltségeik.

\section{Irodalom}

[1] Kim, B. S.: Atopic dermatitis. Medscape. http://emedicine. medscape.com/article/1049085-overview\#aw2aab6b2b2

[2] Weston, L. W., Howe, W.: Treatment of atopic dermatitis. UpTo Date. http://www.uptodate.com/contents/treatment-of-atopic-dermatitis-eczema?source=search_result\&search=treatment+ of+atopic+dermatitis\&selectedTitle $=1 \sim 150 \# \mathrm{Hl}$

[3] Holm, E. A., Wulf, H. C., Stegmann, H., et al.: Life quality assessment among patients with atopic eczema. Br. J. Dermatol., 2006, 154(4), 719-725.

[4] Liezmann, C., Klapp, B., Peters, E. M.: Stress, atopy and allergy: A re-evaluation from a psychoneuroimmunologic perspective. Dermatoendocrinol., 2011, 3(1), 37-40.

[5] Jensen, M. P., Day, M. A., Miró, J.: Neuromodulatory treatments for chronic pain: efficacy and mechanisms. Nat. Rev. Neurol., 2014, 10(3), 167-178.

[6] Bányai, É.: Hypnosis in the light of neuroscience. In: Vértes, G. (ed.): Hypnosis - hypnotherapy. [A hipnózis az idegtudomány fényében. In: Vértes, G. (szerk.): Hipnózis - hipnoterápia]. Medicina Könyvkiadó, Budapest, 2015. [Hungarian]

[7] Mészáros, I.: The history of hypnosis. In: Vértes, G. (ed.): Hypnosis - hypnotherapy. [A hipnózis története. In: Vértes, G. (szerk.): Hipnózis - hipnoterápia.] Medicina Könyvkiadó, Budapest, 2015. [Hungarian]

[8] Kiblstrom, J. F.: The domain of hypnosis, revisited. In: Barnier, A. J., Nash, M. R. (eds.): The Oxford handbook of hypnosis. Oxford University Press, New York, 2008.

[9] Ewin, D. M.: Emergency room hypnosis for the burned patient. Am. J. Clin. Hypn., 1986, 29(1), 7-12.

[10] Jakubovits, E.: Possibilities of hypnosis and hypnosuggestive methods in oncology. [A hipnózis és a hipnoszuggesztív módszerek lehetőségei az onkológiában.] Magy. Onkol., 2011, 55(1), 22-31. [Hungarian] 
[11] Enqvist, B., von Konow, L., Bystedt H.: Pre- and perioperative suggestion in maxillofacial surgery: effects on blood loss and recovery. Int. J. Clin. Exp. Hypn., 1995, 43(3), 284-294.

[12] Meurisse, M., Defechereux, T., Hamoir, E., et al.: Hypnosis with conscious sedation instead of general anaesthesia? Applications in cervical endocrine surgery. Acta Chir. Belg., 1999, 99(4), 151158

[13] Moore, M., Tasso, A. F.: Clinical hypnosis: the empirical evidence. In: Barnier, A. J., Nash, M. R. (eds.): The Oxford handbook of hypnosis. Oxford University Press, New York, 2008.

[14] Shenefelt, P. D.: Hypnosis in dermatology. Arch. Dermatol., 2000, 136(3), 393-399.

[15] Stewart, A. C., Thomas, S. E.: Hypnotherapy as a treatment for atopic dermatitis in adults and children. Br. J. Dermatol., 1995, 132(5), 778-783.

[16] Beck, A. T., Ward, C. H., Mendelsohn, M., et al.: Beck Depression Inventory. In: Perczel Forintos, D., Ajtay, Gy., Kiss, Zs. (eds.): Questionnaires in clinical psychology. [Beck Depresszió Becslőskála. In: Perczel Forintos, D., Ajtay, Gy., Kiss, Zs. (szerk.): Kérdőívek, becslőskálák a klinikai pszichológiában.] (Translated by Kopp, M.) Országos Pszichiátriai és Neurológiai Intézet, Budapest, 2007. [Hungarian]

[17] Spielberger, C.: State-Trait Anxiety Inventory. In: Perczel Forintos, D., Ajtay, Gy., Kiss, Zs. (eds.): Questionnaires in clinical psychology. [Szorongás Állapot Becslőskála. In: Perczel Forintos, D., Ajtay, Gy., Kiss, Zs. (szerk.):Kérdőívek, becslőskálák a klinikai pszichológiában.] (Translated by Sipos, K., Sipos, M.) Országos Pszichiátriai és Neurológiai Intézet, Budapest, 2007, [Hungarian]

[18] Salkovskis, P. M., Rikmes, K. A., Warwick, H. M., et al.: Health Anxiety Inventory - short version. In: Perczel Forintos, D., Ajtay, Gy., Kiss, Zs. (eds.): Questionnaires in clinical psychology. [Egészséggel kapcsolatos szorongás becslőskála - rövid változat. In: Perczel Forintos, D., Ajtay, Gy., Kiss, Zs. (szerk.): Kérdő́ívek, becslőskálák a klinikai pszichológiában.] (Translated by Perczel
Forintos, D., Giles, I.) Országos Pszichiátriai és Neurológiai Intézet, Budapest, 2007. [Hungarian]

[19] Kerns, R. D., Turk, D. C., Rudy, T. E.: The West Haven-Yale Multidimensional Pain Inventory (WHYMPI). Pain, 1985, 23(4), 345-356.

[20] Paykel, E. S.: Stress and life events. In: Perczel Forintos, D., Ajtay, Gy., Kiss, Zs. (eds): Questionnaires in clinical psychology. [Stressz és életesemények. In: Perczel Forintos, D., Ajtay, Gy., Kiss, Zs. (szerk.): Kérdő́ivek, becslőskálák a klinikai pszichológiában.] (Translated by Tringer, L., Veér, A.) Országos Pszichiátriai és Neurológiai Intézet, Budapest, 2007. [Hungarian]

[21] Weismann, A. N., Beck, A. T.: The dysfunctional attitude scale. In: Perczel Forintos, D, Ajtay, Gy, Kiss, Zs. (eds.): Questionnaires in clinical psychology. [Kérdő́ívek, becslőskálák a klinikai pszichológiában.] (Translated by Kopp, M.) Pszichiátriai és Neurológiai Intézet, Budapest, 2007. [Hungarian]

[22] Jensen, M. P.: Hypnosis for chronic pain management. Oxford University Press, New York, 2011

[23] Graffin, N. F., Ray, W. J., Lundy R.: EEG concomitants of hypnosis and hypnotic susceptibility. J. Abnorm. Psychol., 1995, 104(1), 123-131.

[24] Kárpáti, J.: The role of cognitive behavior therapy in the therapy of a patient with irritable bowel syndrome. In: Perczel Forintos, D., Kiss, Zs. (eds.): Let us believe our eyes! Cognitive behavioural therapy case reports. [A kognitív viselkedésterápiás szemlélet szerepe irritábilis bél szindrómában szenvedő nőbeteg terápiájában. In: Perczel Forintos, D., Kiss, Zs. (szerk.): Higgyünk a szemünknek! Kognitív viselkedésterápiás esettanulmányok.] ELTE Eötvös Kiadó, Budapest, 2010. [Hungarian]

(Perczel Kristóf dr., Budapest, Kútvölgyi út 4., 1125 e-mail: perczelk@gmail.com)

\section{Tisztelt Szerzőink, Olvasóink!}

Az Orvosi Hetilapban megjelenő/megjelent közlemények elérhetőségére több lehetőség kínálkozik.

Rendelhetö különlenyomat, melynek áráról bővebben a www.akkrt.hu honlapon (Folyóirat Szerzöknek, Különlenyomat menüpont alatt) vagy Szerkesztőségünkben tájékozódhatnak.

A közlemények megvásárolhatók pdf-formátumban is, illetve igényelhető Optional Open Article (www.oopenart.com).

Adott dij ellenében az online közlemények bárki számára hozzáférhetök honlapunkon (a közlemények külön linket kapnak, így más oldalról is linkelhetővé válnak).

Bővebb információ a hirdetes@akkrt.hu címen vagy különlenyomat rendelése esetén a Szerkesztőségtől kérhető. 